\title{
5
}

\section{Some important articles about enterprise integration}

\section{T.J. Williams}

The first ten models or architectures (the labels are synonymous in this context) are grouped in approximately their order of importance as judged by this author. The remainder are listed simply in alphabetical order.

The AMRF model of the U. S. National Institute of Standards and Technology (NIST) (formerly National Bureau of Standards (NBS) is listed first because it was the first model published as a CIM architecture and has been widely accepted.

CIMOSA is listed second because of its major political importance due to its backing by the European Communities and their push for its acceptance as a standard. The ISO TC184/SC5/WG1 group has the mandate from the International Standards Organization to recommend standards in this area and - as of 1992-93 - has its own model to promote in competition with CIMOSA. GRAI-GIM is listed next in its order in the evaluation by the Task Force for this report.

The Purdue University model is the oldest of the reference models but was labelled as Hierarchical Control or Millwide Control during the 1970s and was only recently identified with the title Computer Integrated Manufacturing. This has been due to its process industry application context.

The Case-Western Reserve model is the oldest of all but was confined mainly to its use as a demonstration vehicle for advanced control theory topics. The Computer Integrated Manufacturing International (CAM-I) Model was a precursor to the ISO offering. The Nippon Steel model was the first major attempt to incorporate enterprise requirements in such a model. The Society of Manufacturing Engineers and IBM have similar models to each other.

The book by Thacker ([1], Part II of Section 5.9), published by the Society of Manufacturing Engineers, presents a very interesting and descriptive model of CIM from the viewpoint of the CEO of a company interested in the technology. It also presents a quite thorough discussion (description only) 
of the 'life-cycle' process of CIM system development. However it goes into none of the detail and technology involved in the three references architectures evaluated in this report. It therefore was not included among them, although it is an excellent semitechnical reference to supplement any of them.

\section{$5.1 \quad$ NIST}

United States National Institute of Standards and Technology (NIST), formerly National Bureau of Standards (NBS).

[1] Albus, J., Barbera, A., and Nagel, N., 'Theory and Practice of Hierarchical Control,' Proceedings of the 23rd IEEE Computer Society International Conference, pp. 18-39 (September 1981).

[2] Simpson, J. A., Hocken, R. J., and Albus, J. S., 'The Automated Manufacturing Research Facility of the National Bureau of Standards,' Journal of Manufacturing Systems, Vol. 1, No. 1, pp. 17-32 (1982).

[3] Jones, A and Whitt, N., Eds., Proceedings on Factory Standards Model Conference, National Bureau of Standards, Gaithersburg, Maryland (1985). [4] Jones, A. and McLean, C., 'A Proposed Hierarchical Control Model for Automated Manufacturing Systems,' Journal of Manufacturing Systems, Vol. 5, pp. 15-25 (1986).

[5] Jones, A. Barkmeyer, E. and Davis, W., 'Issues in the Design and Implementation of a System Architecture for Computer Integrated Manufacturing,' Int. J. Computer Integrated Manufacturing, Vol. 2, No. 2, pp. 65-76 (March-April 1989).

\subsection{CIMOSA}

[1] ESPRIT, Project 688, AMICE, OPen Systems Architecture for CIM, Springer Verlag, Belin (1988)

[2] ESPRIT, Project 688, CIMOSA Reference Architecture Specification, ESPRIT Consortium AMICE, Brussels, Belgium (May 1989).

[3] ESPRIT Consortium AMICE, Open System Architecture, CIMOSA, AD 1.0, Architecture Description, ESPRIT Consortium AMICE, Brussels, Belgium (1991).

[4] Anonymous, AMICE: CIMOSA, ESPRIT Project 5288, Milestone M-2, AD 2.0, Volume 2, Architecture Description, Document R0443/1, Consortium AMICE, Brussels, Belgium, (August 24, 1992). 
[5] Beeckman, Dirk, 'CIMOSA: Computer Integrated Manufacturing Open Systems Architecture,' Int. J. Computer Integrated Manufacturing, Vol.. 2, No. 2, pp. 94-105 (March-April 1989).

[6] Jorysz, H. R. and Vernadat, F. B, 'CIMOSA Part 1: Total Enterprise Modelling and Function View,' Int. J. Computer Integrated Manufacturing, Vol. 3, Nos. 3 and 4, pp. 144-156 (1990).

[7] Jorysz, H. R. and Vernadat, F. B., 'CIMOSA Part 2: Information View,' Int. J. ComputerIntegrated Manufacturing, Vol. 3, Nos 3 and 4, pp. 157-167 (1990).

[8] Klittich, M., 'CIMOSA Part 3: CIMOSA Integrating Infrastructure The Operational Basis for Integrated Manufacturing Systems,' Int. J. Computer Integrated Manufacturing, Vol. 3, Nos. 3 and 4, pp. 168-180 (1990).

\subsection{ISO/TC-184/SC5/WG1 REFERENCE MODEL FOR COMPUTER INTEGRATED MANUFACTURING}

[1] ISO (International Organization for Standardization), ISO TC184/SC5/ WG1, 'The Ottawa Report on Reference Models for Manufacturing Standards,' Report N51 (September 14, 1986).

[2] 2.Thomson, V. and Graefe, U., '1CIM - A Manufacturing Paradigm, SME MM86-722,' 5th Canadian CAD/CAM and Robotics Conference, Toronto (1986).

[3] .CIM Reference Model Working Group, ISO/TC184/SC5/WG1, Technical Report on CIM Reference Model (July 1987).

[4] ISO (International Organization for Standardization), 'Reference Model for Shop Floor Standards, Part 1,' ISO TC184/SC5 N131 (July 15, 1988).

[5] Graefe, U. and Thomson, V. 'A Reference Model for Production Control,' Int. J. Computer Integrated Manufacturing , Vol. 2, No. 2, pp. 86-93 (March-April 1989).

[6] ISO/TC184/SC5/WG1, 'Reference Model for Shop Floor Production Standards, Part 1: A Reference Model for Standardization and a Methodology for Identification of Standards Requirements,' Technical Report (1989).

\subsection{GRAI LABORATORY, UNIVERSITY OF BORDEAUX}

[1] Doumeingts, G., Methode de Conception des Systemes en Productique, Thesis d'etat en Automatique, Universite de Bordeaux I, Bordeaux, France (November 13, 1984). 
[2] Doumeingts, G., Vallespir, B. Darracar, d. and Roboam, M., 'Design Methodology for Advanced Manufacturing Systems,' Computers in Industry, Vol. 9, No. 4, pp. 271-296 (December 1987).

[3] Doumeingts, G., Vallespir, B., Zanettin, M., and Chen, D., GIM, GRAI INTEGRATED METHODOLOGY, A Methodology for Designing CIM Systems, Version 1.0, Unnumbered Report, LAP/GRAI, University Bordeaux 1, Bordeaux, France (May 1992).

\subsection{PURDUE LABORATORY FOR APPLIED INDUSTRIAL CON- TROL, PURDUE UNIVERSITY}

[1] Williams, T. J., 'Computer Control in the Steel Industry,' Computers in Mechanical Engineering, Vol. 2, No. 4, pp. 14-26 (January 1984).

[2] Project Staff, Tasks and functional Specifications of the Steel Plant Hierarchical Control System, Report Number 98, Purdue Laboratory for Applied Industrial Control, Purdue University, West Lafayette, IN (September 1977; Revised June 198). Published in Book Form as: Williams, T. J., Editor, Analysis and Design of Hierarchical Control Systems, Elsevier Science Publishers, Amsterdam, The Netherlands (1985).

[3] Brewster, D. B., Uronen, P. and Williams, T. J., Hierarchical Computer Control in the Paper Industry, Report Number 111, Purdue Laboratory for Applied Industrial Control, Purdue University, West Lafayette, IN (March 1985).

[4] Systems Engineering Group, INCOS Project, Tasks and Functional Specifications of the Bhilai Steel Plant Integrated Control System (INCOS), Steel Authority of India, Ltd., Delhi, India (April 1986).

[5] McCarthy, J. J and Ruckman, R. P., 'The Application of the CIM Reference Model to a Continuous Process Plant,' Advanced Control in Computer Integrated Manufacturing, Morris, H. M., Kompass, E. J. and Williams, T. J., Editors, Purdue University, West Lafayette, IN, pp. 87-96 (September 28-30, 1987).

[6] Williams, T. J., Editor, A Reference Model for Computer Integrated Manufacturing (CIM), A Description From the Viewpoint of Industrial Automation, Minutes, CIM Reference Model Committee, International Purdue Workshop on Industrial Computer Systems, Purdue University, West Lafayette, IN (1988), Instrument Society of America, Research Triangle Park, NC (1989).

[7] Williams, T. J., 'A Reference Model for Computer Integrated Manufacturing From the Viewpoint of Industrial Automation,' International Journal 
of Computer Integrated Manufacturing, Vol. 2, No. 2, pp. 114-127 (MarchApril 1989).

[8] William, T. J., The Purdue Enterprise Reference Architecture, Report Number 154, Purdue Laboratory for Applied Industrial Control, Purdue University, West Lafayette, IN (1991). Also published Instrument Society of America, Research Triangle Park, North Carolina (1992).

\subsection{SYSTEMS RESEARCH CENTER, CASE-WESTERN RESERVE UNIVERSITY}

[1] Findeisen, W. and Lefkowitz, I., 'Design and Applications of Multilayer Control,' Proc. Fourth IFAC Congress, Warsaw, Poland (1969).

[2] Mesarovic, M. D., 'Multilevel Systems and Concepts in Process Control,' Proc. of IEEE, 58, 111-125 (1970).

[3] Mesarovic, M. D., Macko, D. and Takahara, Y., Theory of Hierarchical Multilevel Systems, Academic Press, New York (1970).

[4] Schoeffler, J. D., 'Multilevel Systems and Decomposition for the Solution of Static Optimization Problems; Decomposition and Multilevel Methods of On Line Computer Control of Industrial Processes,' In Wismer, D. A., Ed., Optimization Methods for Large Scale Systems, McGraw Hill, New York (1970).

\subsection{COMPUTER-AIDED MANUFACTURING INTERNATIONAL}

[1] Anonymous, Functional Specification for An Advanced Factory Management System, Report R-79-JSIG-01, CAM-I Incorporated, Arlington, Texas (March 1979).

[2] Boykin, III, R.E., 'CAM-I, CIM Reference Model', Proceedings of the CIMCON '90, NIST Special Publication 785, National Institute of Standards and Technolgy, Gaithersburg, Maryland, pp 35-41 (May 1990).

[3] Throop, J. W. and Read, R. R., A Discrete Parts Manufacturing Model, Report Number R-83-SC-01, Computer-aided Manufacturing International, Inc., Arlington, Texas (August 1983).

[4] Lui, J., 'The CAM-I Advanced Factory Automation System,' Proceedings on Factory Standards Model Conference, National Bureau of Standards, Gaithersburg, Maryland (1985). 


\subsection{NIPPON STEEL CORPORATION}

[1] Anonymous, Industrial Automation System Model, Nagoya Works, Nippon Steel Corporation, Nagoya, Japan (June 11, 1987).

[2] See Appendix V in [6], Section 5.5, of this bibliography for the discussion and presentation of this model.

\subsection{SOCIETY OF MANUFACTURING ENGINEERS (SME)}

Part I

[1] Bertain, L. and Hales, L., Eds., A Program Guide for CIM Implementation, Second Edition, Society of Manufacturing Engineers, Dearborn, MI (1987).

[2] Bertai, L., CIM Implementation Guide, Third Edition, Computer and Automation Systems Association, Society of Manufacturing Engineers, Dearborn, MI (1991).

Part II

[1] Thacker, R. M., A Blueprint for the Computer Integrated Manufacturing Enterprise, Society of Manufacturing Engineers, Dearborn, MI (1989).

\subsection{INTERNATIONAL BUSINESS MACHINES CORPORATION (IBM)}

\section{Part I}

[1] Anonymous, Computer Integrated Manufacturing, The CIM Enterprise, Document G320-9802-00, International Business Machines Corporation, White Plains, NY (April 1989).

[2] Anonymous, IBM CIM Architecture, Document G520-6686-00, International Business Machines Corporation, White Plains, NY (October 1989).

Part II

[1] Bachman, J. A., 'A Framework for Information Systems Architecture,' IBM Systems Journal, Vol 26, No. 3, pp. 276-292 (1987).

[2] Zachman, J. A. Application and Data: Factory of the Future, Applications Technology Group, Information Systems Department, International Business Machines Corporation, Los Angeles, CA (May 23, 1989). 


\subsection{AMERICAN SOCIETY FOR TESTING AND MATERIALS (ASTM)}

[1] Subcommittee E31.20, Computerized Manufacturing, of committee E31, Computerized Systems, American Society for Testing and Materials, 'Standard Guide for Procurement of Computer-Integrated Manufacturing Systems,' Standard E 1383-89, Annual Book of ATM Standards, Vol. 14.01(Approved January 27, 1989, Published March 1989).

\subsection{CARNEGIE-MELLON UNIVERSITY}

[1] Beck, C. L., Modelling and Simulation of Flexible Control Structures for Automated Manufacturing Systems, Technical Report, Robotics Institute, Carnegie-Mellon University (1985).

\subsection{DIGITAL EQUIPMENT CORPORATION (DEC)}

[1] Flateau, U., Digital's CIM Architecture, Revision 1.1, Digital Equipment Corporation, Marlboro, MA (April 1986).

[2] Digital Equipment Corporation, Proceedings, CIM Management Forum for the Process Manufacturing Industries, Orlando, Florida (January 25-27, 1988).

\subsection{HONEYWELL, INC.}

[1] McCarthy, J. J. and Mikkilineni, K., 'Considerations for Distributed Data Bases in the Computer Integrated Business,' Paper presented at the 43rd Annual Conference and Exhibition, Instrument Society of America, Houston, TX (October 16-21, 1988).

[2] Mikkilineni, K., Clark, B., Jenne, T., and Krueger, K., HCAM Architecture 1988 Final Report, Vol. 1-4, Honeywell (1988).

[3] Anderson, A., Jenne, T. Mikkilineni, K., HCAM Architecture 1989 Final Report, Vol. 1 and 2, Honeywell, (1989).

[4] Anderson, A., Jenne, T. and Mikkilineni, K., 'CIM Architecture: One Perspective,' Honeywell, Inc., Minneapolis, MN (1990). Also Proceedings of CIMCON '90, NIST Special Publication 785, National Institute of Standards and Technology, Gaithersburg, Maryland, pp 506-524 (May 1990). 


\subsection{INDUSTRIAL TECHNOLOGY INSTITUTE (ITI)}

[1] Parunak, H.V.D., White, J. F., Judd, R., Irish, B.W. and Kendrick, J., An Architecture for Heuristic Factory Control, Industrial Technology Institute, Ann Arbor, MI (March 26, 1986).

[2] Parunak, H.V., and White, J.F., 'A Framework for Comparing Factory Reference Models', 1987 IEEE Workshop on Languages for Automation, Vienna, Austria, (August 24-27, 1987).

[3] Judd, R.P., Vanderbik, R.S., Brown, M.S., and Sauter, J.A., 'Manufacturing System Design Methodology: Execute the Specifications (X Spec)', Proceedings of CIMCON '90 NIST Special Publication 785, National Institute of Standards and Technology, Gaithersburg, Maryland, pp 133-152, (May 1990).

\subsection{THE PROCOS-A/S SYSTEM}

[1] Moss, S. P., 'A Management and Control Architecture for Factory-Floor Systems: From Concept to Realty,' Int. J. Computer Integrated Manufacturing, Vol. 2, No. 2, pp. 106-113 (March-April 1989).

\subsection{SI GROUPS - LOUGHBOROUGH UNIVERSITY, UK}

[1] Weston, R. H., Hodgson, A., Gascoigne, J. D., Sumpter, C. M., Rui, A. and Coutls, I., 'Configuration Methods and Tools for Manufacturing Systems Integration,' Int. J. Computer Integrated Manufacturing, Vol. 2, No. 2, pp. 77-85 (March-April 1989).

\subsection{SOFTECH, INC. (ICAM)}

[1] SOFTECH, Inc., Integrated Computer-Aided Manufacturing (ICAM), Task I - Final Report, Manufacturing Architecture, Air Force Materials Laboratory, Wright Patterson Air Force Base, OH (November 1978).

\subsection{UNIVERSITY OF TWENTE, THE NETHERLANDS}

[1] Biemans, F. P. M., A Reference Model for Manufacturing Planning and Control, Doctoral Dissertation, University of Twente, Enschede, The Neth- 
erlands (October 27, 1989). Published by: CID-Gigevens Koninklijke Bibliotheek, Den Haag, The Netherlands (1989).

[2] Biemans, F.P.M. and Vissers, C.A., 'A Systems Theoretic View of Computer Integrated Manufacturing', Proceedings of the CIMCON '90 NIST Special Publication 785, National Institute, Standards and Technology Gaithersburg, Maryland, pp 390-410 (May 1990).

\subsection{SOME U.S. DEPARTMENT OF DEFENSE MODELS AND ARCHITECTURES FOR WHICH THIS WRITER HAS NO DETAILS AT PRESENT}

1. Honeywell's EIS (Engineering Information System)

2. Product Data Exchange Specification (PDES) by PDES, Inc.

3. SEMATECH CIM Architecture

4. DARPA Initiative Into Concurrent Engineering (DICE) being developed by W Va, CMU and RPI Universities

5. The RPI CIM Model (Rensselaer Polytechnic Institute)

6. Advanced Cost Management System (DOD)

7. Microelectronics Manufacturing Science and Technology (MMST) DOD

8. CFI (DOD) (CAD Framework Initiative)

9. Lehigh University, AMEF, Agile Manufacturing Enterprise Forum. (No Specific Reference Avaliable).

The above list developed by:

Enterprise Integration Framework Project,

Federal Systems Division,

IBM Corporation, Oswego, NY 13827, USA

\subsection{SOME ADDITIONAL MODELS RECOMMENDED FOR STUDY BY THE ISO WORKING GROUP, ISO/TC-184/SC5/WG1}

1. Additional Models Recommended for Study by ISO/TC-184/SC5/WG1

2. EISWG (MCC) (Enterprise Integration Suppliers Working Group)

3. EIP (Enterprise Integration Program)

4. NCMS/CIO (National Center for Manufacturing Studies) (DFI)

5. CASEE (Hewlett-Packard)

6. OMG (Object Management Group)

7. $\mathrm{C} 4(\mathrm{GM})$

8. PWAF (Plant With a Future - Caterpillar) 


\subsection{SOME PUBLICATIONS OF GENERAL IMPORTANCE IN THE} STUDY OF CIM REFERENCE MODELS AND ARCHITECTURES

[1] Jones, A., and Davis W., Eds., 'Special Issue on Architectures and Implementation,' Int. J. Computer Integrated Manufacturing, Vol. 2, No. 2, London (March-April 1989). This issue contains six articles and is an excellent review of the field as of its date of publication.

[2] Merchant, M. E., Nemes, L. and Bernus, P., Special Issue, Joseph Hatvany Memorial, Computers in Industry, Vol. 14, No. 1-3 (May 1990).

[3] Milacic, V. R. and Majstorovic, V. D., Eds., Special Issue, Intelligent Manufacturing Systems - IMS'89, Computers in Industry, Vol. 15, No. 1-2, pp. 1-162 (October 1990).

[4] Panel on Technical Barriers to Computer Integration of Manufacturing, A Research Agenda for CIM, Information Technology, National Research Council, National Academy Press, Washington, D.C. (1988).

[5] Sobczak, T. V., Ed., A Glossary of Terms for Computer Integrated Manufacturing, Computer and Automated Systems Association of SME, Dearborn, MI (1984).

[6] U.S. Congress, Office of Technology Assessment, Making Things Better: Competing in Manufacturing, OTA-ITE-443, U.S. Government Printing Office, Washington, D.C. (February 1990). 